\title{
RANCANG BANGUN SISTEM INFORMASI ADMINISTRASI KEUANGAN BERBASIS WEB PADA SMK NU UNGARAN
}

\author{
Deni Prayoko Wijayanto*, Agung Riyantomo dan Nugroho Eko Budiyanto \\ Program Studi Teknik Informatika Fakultas Teknik Universitas Wahid Hasyim Semarang \\ Jl. Menoreh Tengah X/22 Sampangan Semarang 50236 \\ *Email: pradenny@gmail.com
}

\begin{abstract}
Abstrak
Suatu lembaga pendidikan memerlukan pengelolaan manajemen yang baik untuk melayani kebutuhan peserta didik. Untuk itu proses pendataan peserta didik baru yang benar serta administrasi keuangan peserta didik sangatlah berperan di lembaga pendidikan tersebut. SMK NU Ungaran merupakan salah satu SMK Rujukan di Jawa Tengah dari tahun 2016, SMK NU Ungaran ingin meningkatkan mutu pelayanan mereka, salah satunya pelayanan dalam administrasi keuangan pembayaran peserta didik. Dalam melakukan kegiatan administrasi pembayaran Sumbangan Pembinaan Pendidikan (SPP) dan insidental sudah menggunakan komputer, namun belum terkomputerisasi dan masih ada dokumen yang dikerjakan secara manual serta pengolahan data belum terpusat dan terintegrasi. Penelitian ini memiliki tujuan utama agar terbangunnya sistem informasi administrasi keuangan berbasis web pada SMK NU Ungaran yang nantinya dapat digunakan dalam membantu menyelesaikan permasalahan administrasi keuangan khususnya dalam hal penagihan yang sifatnya berkala juga penyediaan layanan informasi keuangan yang lebih baik kepada perserta didik.
\end{abstract}

Kata Kunci : sistem informasi, peserta didik, administrasi, keuangan, pembayaran,

\section{PENDAHULUAN}

SMK NU Ungaran adalah sekolah di bawah naungan Lembaga Pendidikan Ma'arif NU yang didirikan pada tanggal 19 Mei 2003 oleh Ulama NU Kabupaten Semarang yang dimotori oleh K.H. Abdul Wahab (KaumanUngaran). Setelah diraihnya sertifikat Sistem Manajemen Mutu ISO 9001:2008 dari LAPMO American pada bulan Mei tahun 2012, dan termasuk sebagai salah satu SMK Rujukan di Jawa Tengah pada tahun 2016, SMK NU Ungaran ingin meningkatkan mutu pelayanan mereka, salah satunya pelayanan dalam administrasi pembayaran peserta didik. Melalui tata usaha segala administrasi peserta didik dikelola dengan pelayanan yang baik. Dalam melakukan kegiatan administrasi pembayaran Sumbangan Pembinaan Pendidikan (SPP) dan insidental, masih dikerjakan secara manual serta pengolahan data belum terpusat dan terintegrasi.

Untuk itu, perlu suatu sistem yang terpusat dan terintegrasi guna mencapai dan mempercepat proses pemasukan data dan pelaporan. sehingga mempermudah dalam pencarian data peserta didik yang diperlukan dan dalam hal pembuatan laporan bulanan maupun surat tagihan menjadi lebih cepat dan tepat waktu. Sistem ini nantinya akan berbasis intranet agar seluruh warga sekolah bisa mengakses di lingkungan sekolah.
Adapun tujuan dalam penulisan penelitian ini adalah :

1. Menghasilkan sistem pembayaran administrasi peserta didik pada SMK NU Ungaran yang terpusat dan terintegrasi.

2. Mempermudah pencarian data bila kartu SPP hilang atau lupa tidak dibawa serta mempermudah dalam pembuatan laporan bulanan maupun surat tagihan, agar lebih cepat, efektif dan efisien.

\section{Tinjauan Pustaka}

Penelitian yang relevan memuat uraian hasil penelitian terdahulu yang mendasari penelitian yang akan penulis lakukan, berbagai penelitian yang sudah pernah dilakukan oleh peneliti terdahulu yang relevan atau berkaitan dengan penelitian yang akan dilakukan saat ini adalah:

A. "Pembangunan Sistem Informasi Pembayaran Sekolah Pada Sekolah Menegah Atas (SMA) Negeri 1 Rembang Berbasis Web" Oleh Heni Dwi Erinawati, 2012.

Dijelaskan bahwa Sistem Informasi Pembayaran Sekolah pada SMA Negeri 1 Rembang masih konvensional dengan mencatat pada kartu pembayaran kemudian data pembayaran direkap secara manual pada buku. Hal ini menyebabkan proses memakan waktu lama dan tingkat 
kesalahan yang besar, selain itu juga tingkat kecepatan akses data (laporannya) jika dibutuhkan sewaktu-waktu dibutuhkan menjadi terlambat.

Penelitian ini memiliki tujuan utama untuk membangun sistem informasi yang dapat digunakan dalam sistem pembayaran sekolah, diharapkan dengan adanya sistem ini memaksimalkan pekerjaan petugas agar target penyampaian informasi, ketelitian, maupun volume pekerjaan dapat ditangani lebih efisien dan efektif.

Sistem pembayaran Sekolah pada SMA Negeri 1 Rembang ini dirancang dengan menggunakan PHP dan MySQL.

B. "Sistem Informasi Administrasi Pembayaran Iuran Bulanan (SPP) dan Dana Sumbangan Pendidikan (DSP) Siswa Taman Kanak-Kanak Negeri Pembina Kecamatan Pringkuku" Oleh Yuanita Sukadi, 2012.

Dalam penelitian ini sistem yang berjalan mulai dari proses pendataan siswa hingga pembayaran keuangan siswa masih kurang efektif dan kurang efisien dimana dalam pencatatan terutama dalam pembayaran SPP dan DSP dilakukan secara berulang-ulang sehingga menyebabkan proses yang lama dalam mengolah data-data dan dapat menghabiskan waktu terutama untuk menentukan sebuah keputusan dalam menindaklanjuti informasi yang di dapat dari siswa.

Penelitian ini bertujuan untuk merancang Sistem Informasi Administrasi Pembayaran SPP dan DSP Taman KanakKanak Negeri Pembina Kecamatan Pringkuku secara terkomputerisasi. Dengan sistem itu diharapkan dapat membantu petugas untuk dapat mempercepat proses pencarian data dan memperkecil resiko kerusakan serta kehilangan data. Dalam pembuatan laporan baik laporan penerimaan iuran bulanan (SPP) maupun laporan penerimaan Dana Sumbangan Pendidikan (DSP) menjadi lebih mudah dan akurat.

\section{Pengertian Sistem}

Sistem merupakan sekumpulan unsur (elemen) yang saling berinteraksi sehingga membentuk satu kesatuan yang utuh dalam usaha mencapai tujuan. Sekolah merupakan suatu sistem, karena sekolah memiliki komponen inti yang terdiri dari masukan (input), pengolahan (processing), dan keluaran (output). Ketiga komponen tersebut tidak dapat dipisahkan antara satu dengan lainnya karena merupakan satu kesatuan utuh yang saling terkait, terikat, mempengaruhi, membutuhkan dan menentukan. (Aan Komariyah \& Cepi Triatna, 2005).

\section{Pengertian Informasi}

Menurut kusrini dan Andri koniyo (2007 : 7) Informasi adalah data yang sudah diolah menjadi sebuah bentuk yang berarti bagi pengguna, yang bermanfaat dalam pengambilan keputusan saat ini atau mendukung sumber informasi. Data belum memiliki nilai sedangkan informasi sudah memiliki nilai. Informasi dikatakan bernilai bila manfaatnya lebih besar dibanding biaya untuk mendapatkannya.

\section{Pengertian Sistem Informasi Manajemen}

Sistem Informasi Manajemen adalah sebuah sistem informasi yang selain melakukan pengolahan transaksi yang sangat berguna untuk kepentingan organisasi, juga banyak memberikan dukungan informasi dan pengolahan untuk fungsi manajemen dalam pengambilan keputusan. (Chr. Jimmy L. Gaol, 2008).

\section{Pembayaran Administrasi Peserta Didik}

Administrasi pembayaran peserta didik adalah suatu kegiatan administrasi yang melayani semua pembayaran peserta didik baik di lembaga pendidikan formal maupun non formal agar berlangsung secara efektif dan efisien dalam mencapai tujuannya. (Eni Wijayanti, Shita Martama Tyas Ningrum, Dewi Ratna Wulansari, 2011)

\section{METODE \\ Metode Pengembangan}

Model pengembangan sistem yang Penulis gunakan adalah pendekatan sistem SLC (System Life Cycle). Menurut MC Leon, terdapat lima tahapan utama dalam SLC dapat terdiri dari Tahap perencanaan (planning phase), analisis (systems analysis), perancangan (design phase), implementasi sistem (implementation systems) dan penggunaan (user phase). (Andri Kristanto, 2008). 


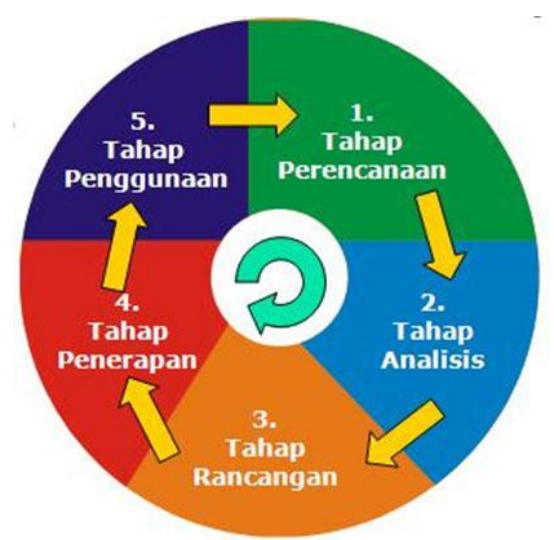

Gambar III.1. Siklus Pengembangan Sistem Metode SLC.

Sumber : Krismiaji, 2010.

\section{Keterangan:}

A. Perencanaan

1. Menentukan lingkup dari sistem. Unit organisasi, kegiatan atau sistem manakah yang terlibat? Mana yang tidak? Informasi ini memberikan perkiraan awal dari skala sumber yang di perlukan.

2. Mengenali berbagai area permasalahan potensial. Perencanaan akan menunjukkan yang mungkin tidak berjalan dengan semestinya sehingga hal ini dapat dicegah.

3. Mengatur urutan tugas. Banyak tugas tugas terpisah yang diperlukan untuk mencapai tugas ini diatur dalam urutan logis berdasarkan prioritas informasi dan kebutuhan akan efisien.

4. Memberikan dasar untuk pengendalian. Tingkat kinerja dan metode pengukuran harus dispesifikasikan sejak awal.

B. Analisa

Setelah tahap perencanaan selesai, Penulis melakukan analisis sistem. Analisis Sistem adalah penelitian atas sistem yang telah ada pada SMK NU Ungaran dengan tujuan untuk merancang sistem baru atau diperbaharui. Langkah - langkah yang ada dalam Tahap Analisa sistem ini adalah :

1. Mengumumkan penelitian sistem

2. Mengorganisasikan tim proyek

3. Mendefinisikan kebutuhan informasi

Analisis mempelajari kebutuhan informasi pemakai dengan terlibat dalam berbagai kegiatan pengumpulan informasi seperti:
a. Wawancara perorangan
b. Pengamatan
c. Pencariana catatan
d. Survey.

4. Mendefinisikan kriteria kinerja sistem.

5. Menyiapkan usulan rancangan

6. Menyetujui atau Menolak Penerapan Sistem

C. Perancangan

Perancangan sistem adalah penentuan proses dan data yang diperlukan oleh sistem baru. Dalam tahap ini penulis menentukan proses dan data yang diperlukan pada Sistem Informasi Pembayaran Administrasi Peserta Didik pada SMK NU Ungaran. Dalam tahap perancangan sistem informasi yang baru ini Penulis menggunakan bahasa pemrograman PHP dan MySQL sebagai media penyimpanan data. Langkah-langkah yang diperlukan dalam tahap perancangan adalah :

1. Menyiapkan Rancangan Sistem yang terinci

2. Mengidentifikasi berbagai alternatif konfigurasi sistem

3. Mengevaluasi berbagai alternatif konfigurasi sistem

4. Memilih konfigurasi terbaik

5. Menyiapkan Usulan Penerapan

6. Menyetujui atau menolak penerapan sistem

D. Penerapan

Setelah perancangan selesai, penulis melakukan penerapan atau implementasi untuk menyatukan sumber daya fisik (hardware, software, dan operator) dengan sumber daya konseptual (perencanaan, analisa, dan perancangan) agar dapat menghasilkan sistem baru yang bekerja dengan baik dan sesuai dengan sistem yang berjalan di SMK NU Ungaran. Tahap-tahap pada penerapan adalah :

1. Merencanakan penerapan

2. Mengumumkan penerapan

3. Mendapatkan sumber daya perangkat keras/lunak

4. Menyiapkan database

5. Menyiapkan fasilitas fisik

6. Mendidik peserta dan pemakai

7. Menyiapkan usulan cutover

8. Menyetujui/menolak masuk sistem baru

9. Masuk ke Sistem Baru

E. Penggunaan

Langkah terakhir adalah tahap penggunaan sistem untuk mencapai tujuan yang telah diidentifikasikan oleh Penulis pada tahap perencanaan. Tahap penggunaan dilakukan setelah diperoleh hasil yang memuaskan pada tahap implementasi atau penerapan sistem. Setelah sistem informasi pembayaran administrasi peserta didik digunakan oleh bagian-bagian yang bersangkutan dengan baik, dapat dilakukan audit sistem yang bertujuan 
untuk menentukan seberapa baik sistem informasi pembayaran administrasi peserta didik tersebut dapat meningkatkan efektivitas dan efisiensi kerja serta dapat menghasilkan informasi yang cepat dan akurat. Pada tahap ini dilakukan juga pemeliharaan sistem yang dilakukan secara berkala. Langkah-langkah yang dilakukan pada tahap penggunaan :

1. Menggunakan sistem

2. Audit sistem

3. Memelihara sistem Pemeliharaan sistem dilaksanakan untuk 3 alasan :

a. Memperbaiki kesalahan

b. Menjaga kemutakhiran sistem

c. Meningkatkan sistem

4. Menyiapkan usulan rekayasa ulang

5. Menyetujui atau menolak rekayasa ulang system

\section{Prosedur Pengembangan}

Dalam rekayasa perangkat lunak konsep SDLC mendasari berbagai jenis metodologi pengembangan perangkat lunak. Metodologimetodologi ini membentuk suatu kerangka kerja untuk perencanaan dan pengendalian pembuatan sistem informasi, yaitu proses pengembangan perangkat lunak.

Dalam pengembangan sistem informasi perlu digunakan metodologi sebagai pedoman bagaimana dan apa yang harus dilakukan selama melaksanakan pengembangan sistem. Adapun pengembangan system yang digunakan adalah paradigma waterfall (classical life cicle), tahapan-tahapannya adalah sebagai berikut :

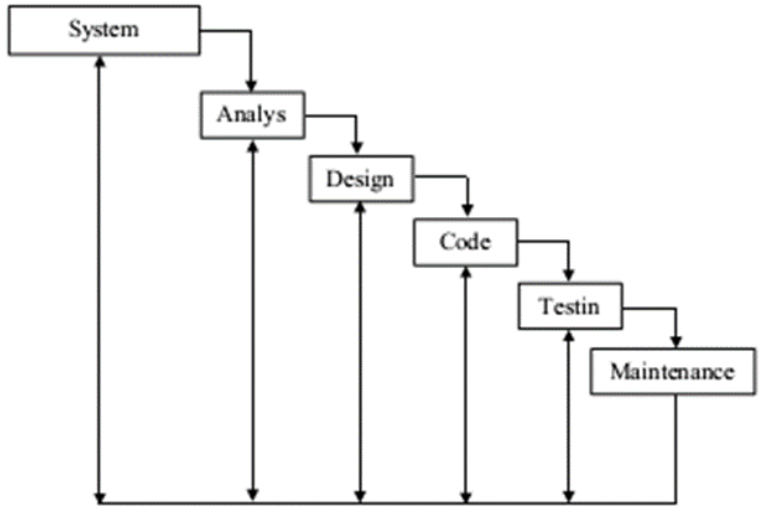

Gambar III.2 Tahapan waterfall.

A. Rekayasa perangkat lunak (system enginerring)

Melakukan pengumpulan data dan penetapan kebutuhan semua elemen system.

B. Requirements analysis
Melakukan analisis terhadap permasalahan yang dihadapi dan menetapkan kebutuhan perangkat lunak, fungsi performsi dan interfacing.

C. Design

Tahapan perancangan bertujuan menterjemahkan persyaratan menjadi suatu bentuk representasi yang dapat dievaluasi kualitasnya sebelum tahapan coding dilakukan.

D. Coding

Pengkodean yang mengimplementasikan hasil desain ke dalam kode atau bahasa yang dimengerti oleh mesin lomputer dengan menggunakan bahasa pemrograman tertentu.

E. Testing ( pengujian)

Tahap ini berfokus pada pengujian rincian logika software. Pengujian bertujuan mengungkapkan dan menghilangkan kesalahankesalahan yang ada sehingga software bekerja sesuai dengan yang diharapkan.

F. Maintenance (perawatan)

Menangani perangkat lunak yang sudah selesai supaya dapat berjalan lancer dan terhindar dari gangguan-gangguan yang dapat menyebabkan kerusakan.

\section{Sistem lama}

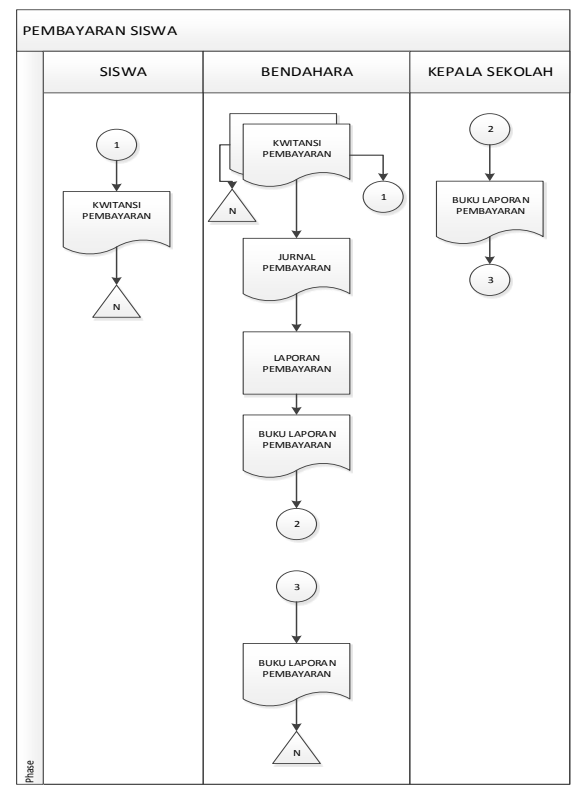

Gambar III.3 Flow Of Document Sistem Lama 


\section{Usulan Sistem Baru}

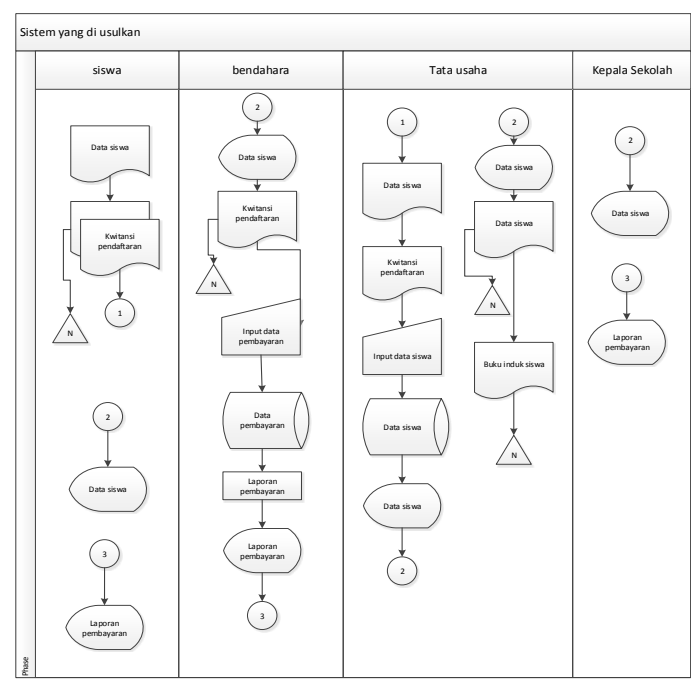

Gambar III.4 Flow Of Document Sistem Baru

Data Flow Diagram (DFD)

\section{Context Diagram}

Berdasarkan identifikasi data dan informasi maka dapat digambarkan Context Diagram sebagai berikut :

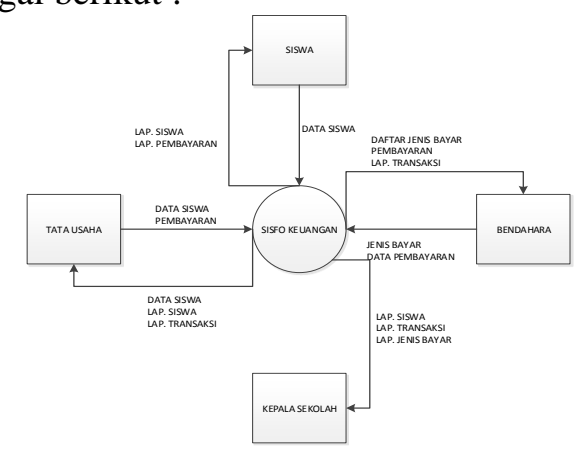

Gambar III.5 Context Diagram

DFD Level 0

\section{Gambar III.6 DFD Level 0}

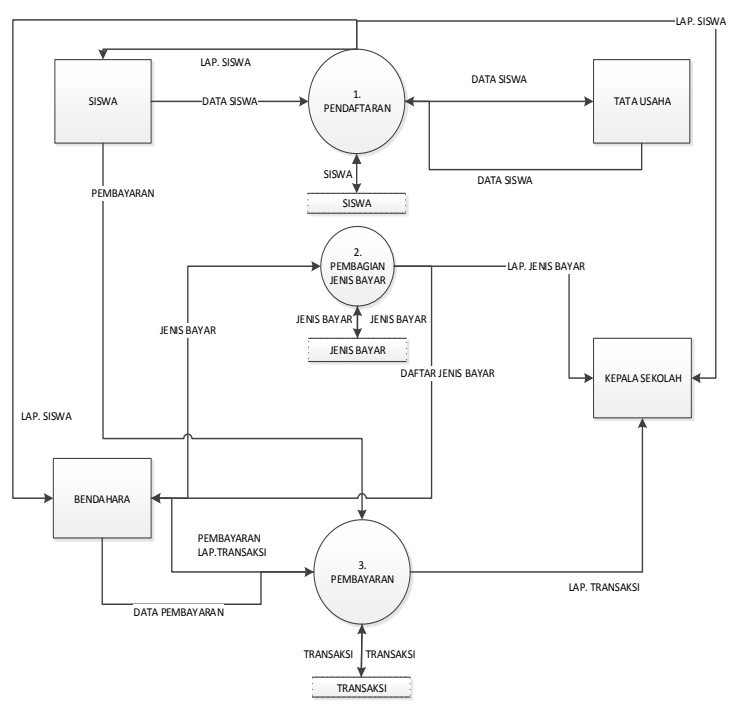

\section{DFD Level 1}

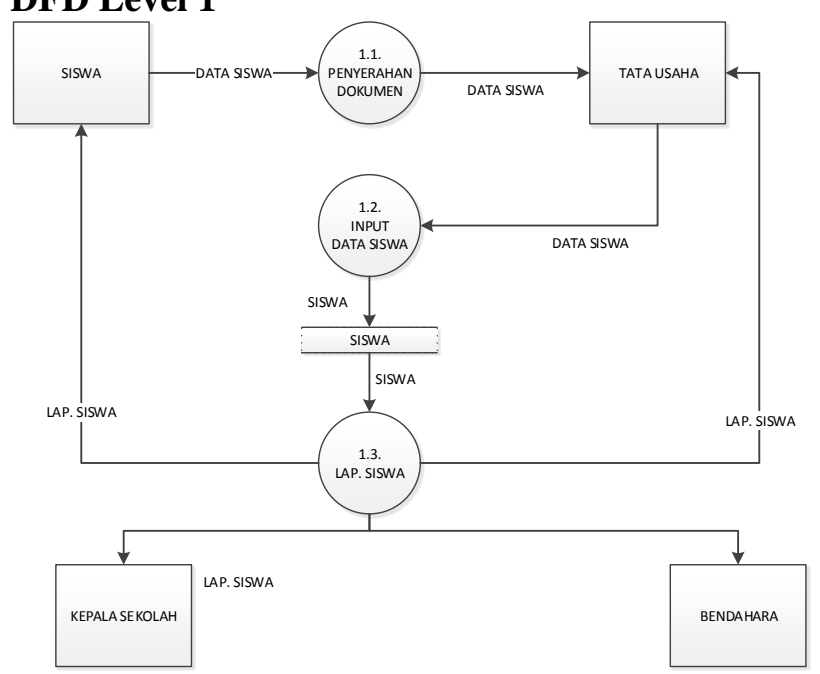

Gambar III.7 DFD Level 1

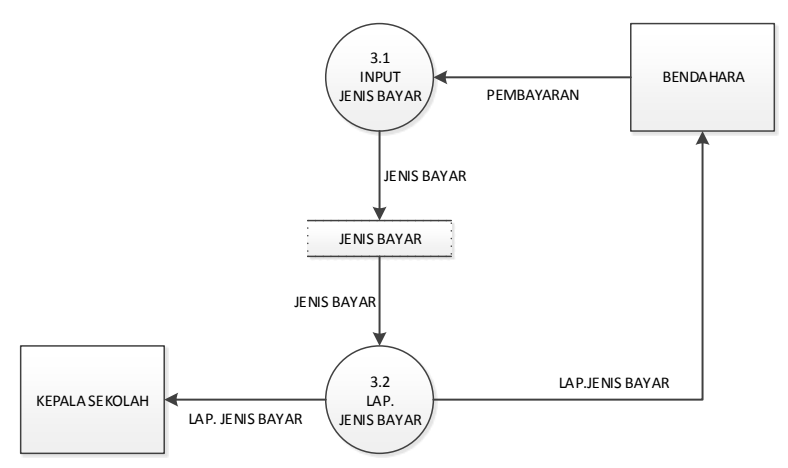

Gambar III.8 DFD Level 1 Input

Pembayaran

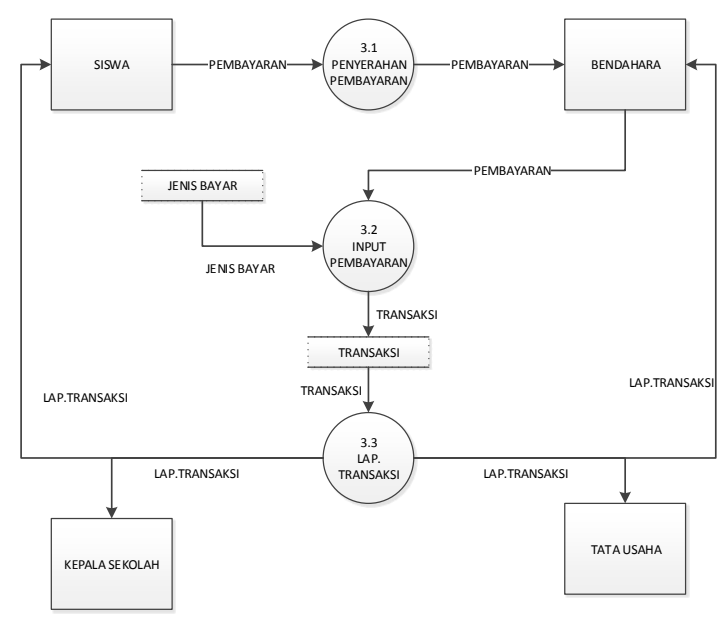

Gambar III.9 DFD Level 1 Penyerahan Pembayaran 


\section{Entity Relationship Diagram (ERD)}

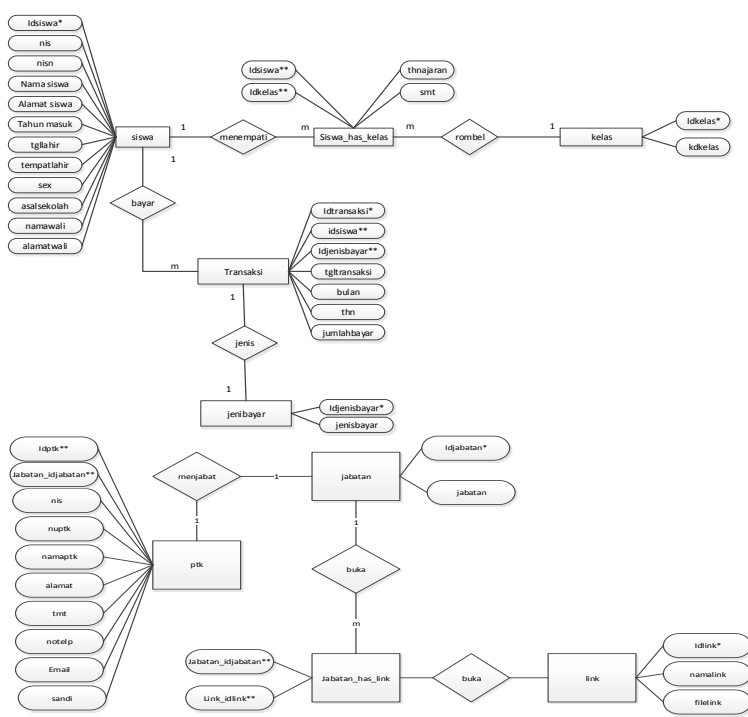

Gambar III.11 Entity Relationship Diagram (ERD).

\section{HASIL DAN PEMBAHASAN \\ Perancangan dan Interface}

Rancangan desain output merupakan suatu rancangan Halaman program yang menampilkan hasil output atau keluaran sesuai dengan yang diinginkan berdasarkan rancangan desain input yang sudah dijelaskan sebelumnya. Beberapa rancangan desain output yang ditampilkan diantaranya:

1. Login

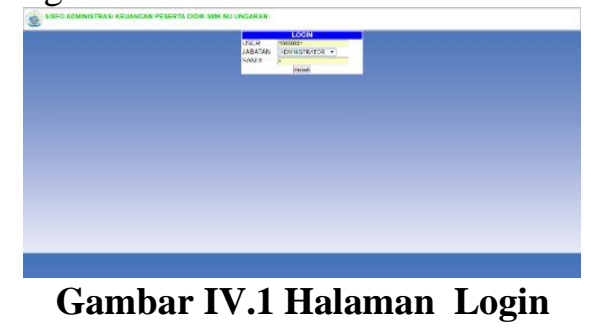

Keterangan :

Form Login ini berisi Halaman untuk melakukan login. Setiap user dapat melakukan login dengan nama dan password masingmasing

2. Setting User

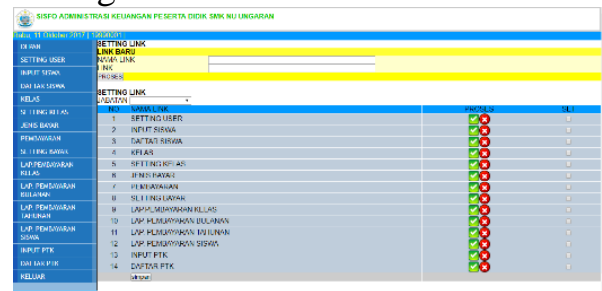

Gambar IV.2 Setting User

Keterangan :
Setting User ini berisi Halaman untuk melakukan hak Akes dari jabatan sistem. Setiap User mempunyai hak akses tersendiri untuk mengelola sistem.

3. Input Siswa

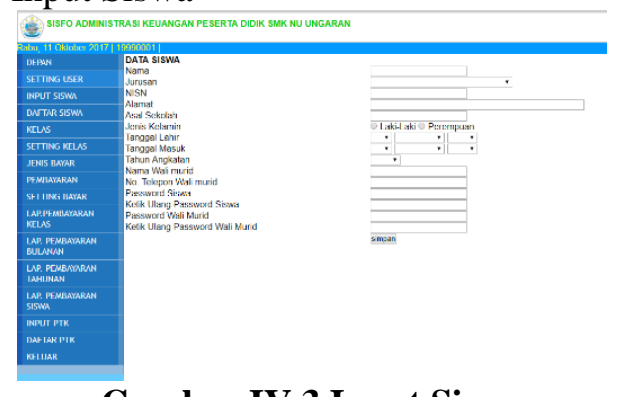

\section{Gambar IV.3 Input Siswa}

Keterangan :

Halaman ini digunakan untuk input data siswa 4. Daftar siswa

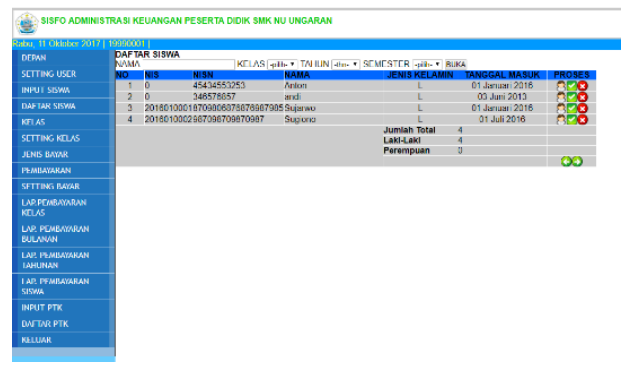

\section{Gambar IV.4 Daftar Siswa}

Keterangan :

Halaman ini digunakan untuk melihat daftar seluruh siswa.

5. Kelas

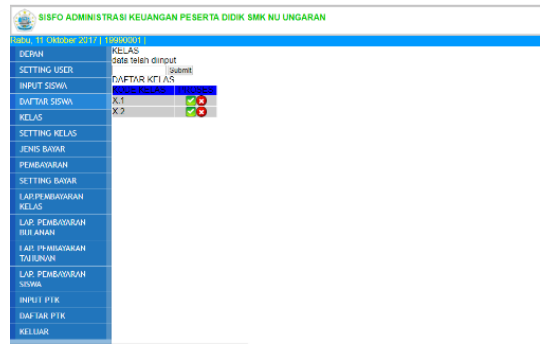

Gambar IV.5 Kelas

Keterangan :

Halaman ini digunakan untuk menambah kelas dan menghapus kelas.

6. Setting Kelas

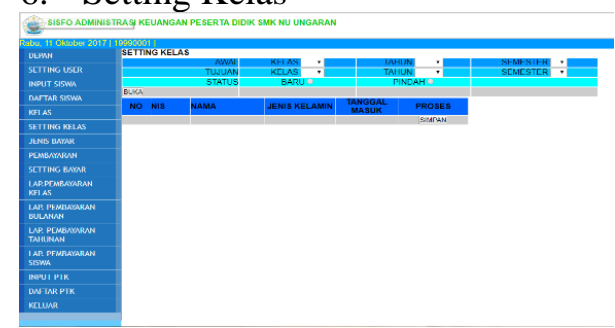

Gambar IV.6 Setting Kelas 
Keterangan :

Halaman ini digunakan untuk memasukkan siswa ke dalam kelas atau memindahkan siswa apabila kenaikan kelas.

7. Jenis Bayar

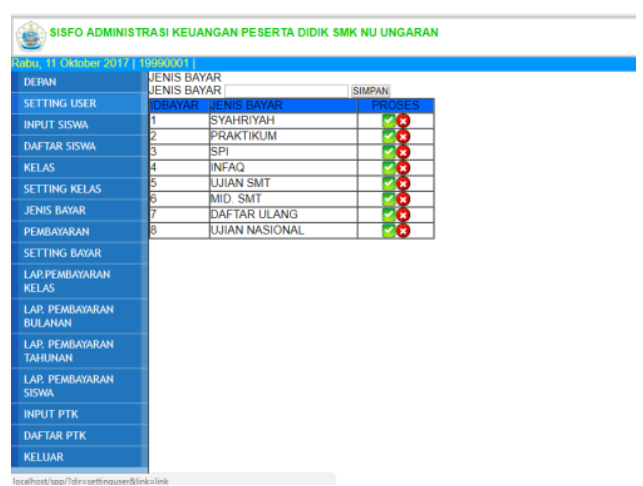

Keterangan :

Gambar IV.7 Jenis Bayar

Halaman ini digunakan untuk melakukan penambahan dan pengurangan jenis transaksi pembayaran.

8. Pembayaran

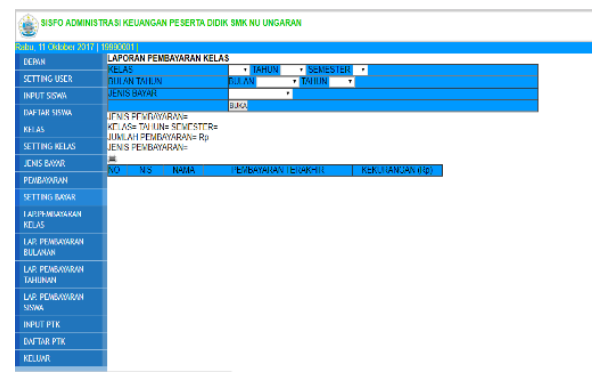

Gambar IV.8 Pembayaran

Keterangan :

Halaman ini digunakan untuk melakukan transaksi pembayaran. Setting Bayar

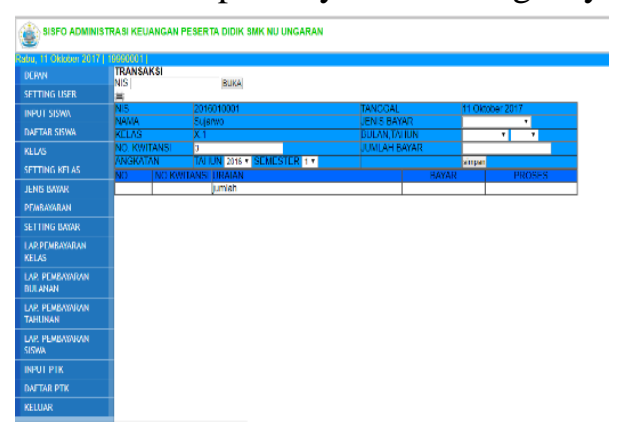

Gambar IV.9 Setting bayar

Keterangan :

Halaman ini digunakan untuk input jumlah pembayaran setiap jenis bayar.

9. Laporan Pembayaran Kelas

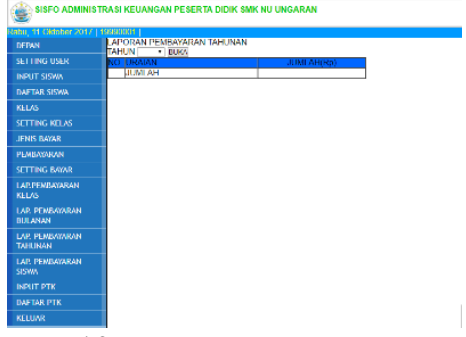

Gambar IV.10 Laporan Pembayaran Kelas Keterangan :

Halaman ini digunakan untuk melihat laporan pembayaran setiap kelas.

10. Laporan Pembayaran Bulanan

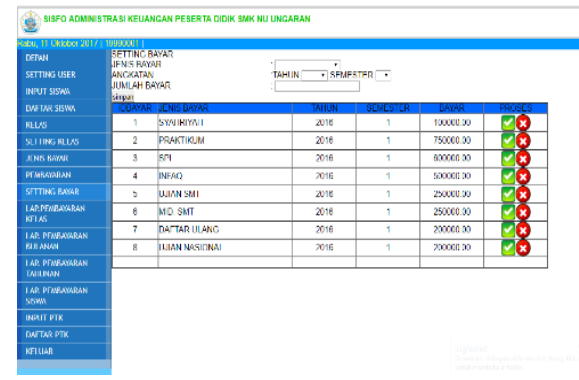

Gambar IV.11 Laporan Pembayaran Bulanan

Keterangan :

Halaman ini digunakan untuk melihat laporan pembayaran bulanan

11. Laporan Pembayaran Tahunan

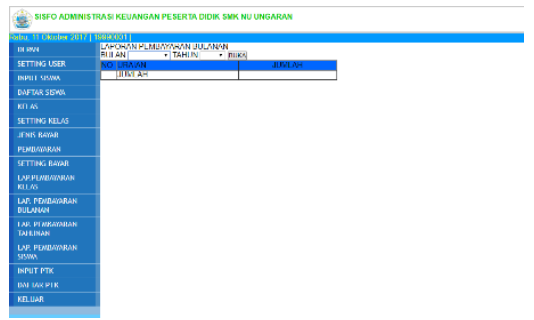

\section{Gambar IV.12 Laporan Pembayaran Tahunan}

Keterangan :

Halaman ini digunakan untuk melihat laporan pembayaran tahunan.

12. Laporan Pembayaran Siswa

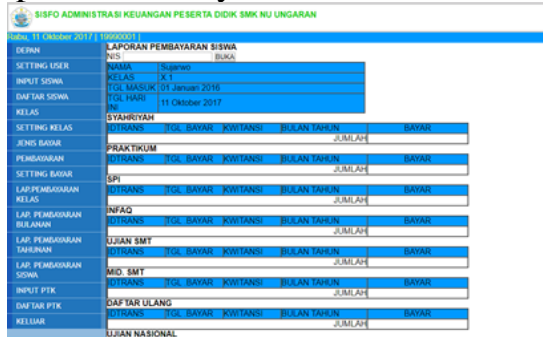

Gambar IV.13 Laporan Pembayaran Siswa

Keterangan :

Halaman ini digunakan untuk melihat laporan pembayaran persiswa.

13. Input Pendidik dan Tenaga Kependidikan 


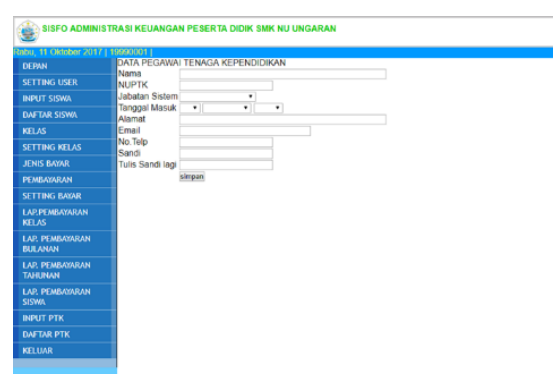

Gambar IV.14 Input Pendidik dan Tenaga Kependidikan

Keterangan :

Halaman ini digunakan untuk mengelola data pegawai dan dapat digunakan

14. Daftar Pendidik dan Tenaga Kependidikan

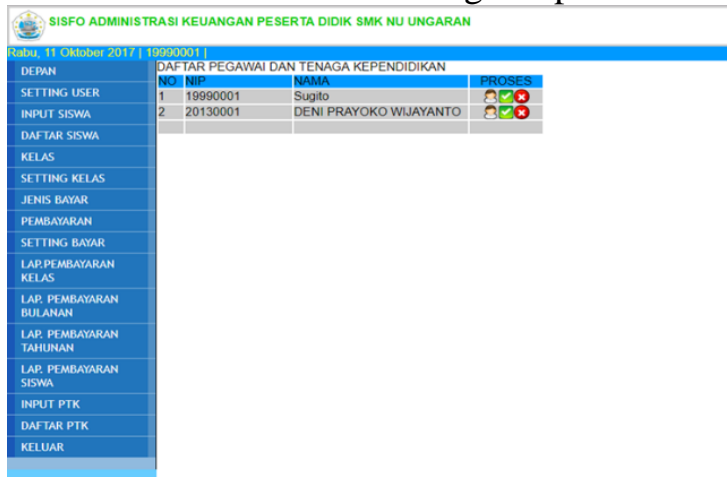

Gambar IV.15 Daftar Pendidik dan Tenaga Kependidikan

Keterangan :

Halaman ini digunakan untuk melihat dan edit data pegawai.

15. Kartu Ujian Semester

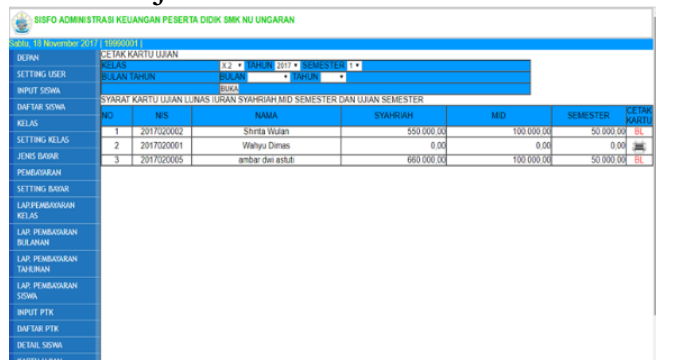

Gambar IV.16 Cetak Kartu Ujian

Keterangan :

Halaman ini digunakan untuk mencetak kartu ujian semester, syarat untuk mencetak kartu ujian harus lunas pembayaran pada semater tersebut. Apabila sudah lunas akan muncul logo print untuk mencetak kartu, tapi apabila belum lunas administrasi keuangan logo print tidak muncul, akan di gantikan dengan logo BL (Belum Lunas).

16. Laporan Kekurangan Pembayaran Siswa

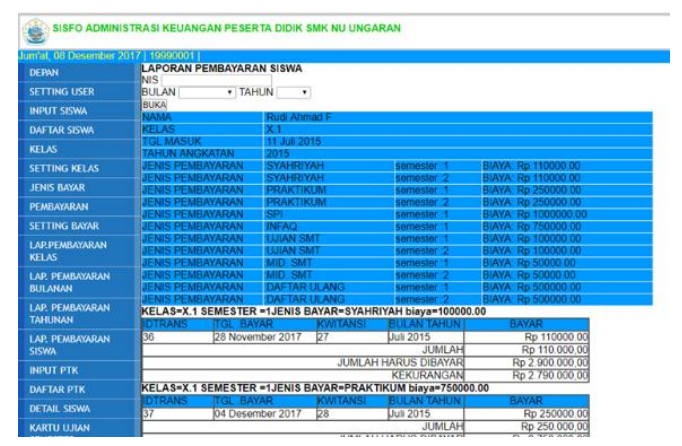

Gambar IV.17 Laporan Kekurangan Pembayaran Siswa

Keterangan :

Halaman ini digunakan untuk melihat kekurangan pembayaran siswa, dari kelas sepuluh, sebelas dan dua belas

\section{KESIMPULAN}

Dari hasil pembahasan diatas mengenai sistem informasi administrasi keuangan berbasis web pada SMK NU Ungaran, maka dapat disimpulkan bahwa :

1. Sistem informasi administrasi keuangan berbasis web, mempermudah Bendahara dan Tata usaha dalam pembuatan laporan bulanan, laporan kelas, laporan tahunan maupun tagihan keuangan siswa, lebih cepat, efektif dan efisien.

2. Sistem informasi administrasi keuangan berbasis web, mempermudah peserta didik untuk melihat data keuangan bila kartu SPP hilang atau lupa tidak dibawa.

\section{Saran}

Berdasarkan hasil pembahasan dan kesimpulan diatas, saran-saran yang dapat Penulis sampaikan adalah sebagai berikut :

1. Sebelum sistem informasi administrasi keuangan berbasis web pada SMK NU Ungaran tersebut diterapkan, perlu diadakan pelatihan bagi Tata Usaha, Bagian Bendahara, Siswa dan Pimpinan dalam menggunakan sistem dengan benar agar pemanfaatan sistem dapat dilakukan dengan maksimal.

2. Setelah penerapan sistem dilakukan, juga perlu dilakukan pengawasan dan pengembangan 
sistem. Hal ini dilakukan agar sistem dapat semakin berkembang dan semakin bermanfaat.

3. Untuk pengembangan selanjutnya program ini tidak hanya dapat digunakan untuk administrasi keuangan peserta didik saja, tapi juga dapat digunakan untuk penggajian pendidik dan tenaga kependidikan di SMK NU Ungaran.

\section{DAFTAR PUSTAKA}

Aan Komariyah, Cepi Triatna, 2005, "Visionary Leadership Mепијu Sekolah Efektif", Jakarta : Bumi Aksara

Andri Kristanto, 2008, "Perancangan Sistem Informasi dan Aplikasinya", Gava Media,Yogyakarta.

Chr.Jimmy L.Gaol, 2008, "Sistem Informasi Manajemen”, Jakarta : Grasindo

Eni Wijayanti, Shita Martama Tyas Ningrum, Dewi Ratna Wulansari, 2011, "Sistem Informasi Pembayaran SPP SMK N 1 Pada Pandak Bantul", STMIK AMIKOM Yogyakarta

Heni Dwi Erinawati, 2012, "Pembangunan Sistem Informasi Pembayaran Sekolah Pada Sekolah Menegah Atas (SMA) Negeri 1 Rembang Berbasis $W e b^{\prime \prime}$, Indonesian Jurnal on Computer Science - Speed (IJCSS) 15 FTI UNSA Vol 10 No 1

Krismiaji, 2010; "Sistem Informasi Akuntansi, Edisi Ketiga", Jakarta : UPP STIM.

Kusrini dan Andri Koniyo, 2007, "Tuntunan Praktis Membangun Sistem Informasi Akuntansi dengan Visual Basic \& Microsoft SQL Server." Yogyakarta : Andi.

Yuanita, 2012, "Sistem Informasi Administrasi Pembayaran Iuran Bulanan (SPP) Dan Dana Sumbangan Pendidikan (DSP) Siswa Taman Kanak-Kanak Negeri
Pembina Kecamatan Pringkuku". Jurnal Speed 13, 9 No 2, 103-108. 